| Research Article / Araştırma Makalesi |

\title{
Exploration of Science Teachers' Views About Socioscientific Issues
}

\section{Fen Bilimleri Öğretmenlerinin Sosyobilimsel Konular Hakkındaki Görüşlerinin Incelenmesi}

\section{Türkan Nur Metin ${ }^{1}$, Dilek Karışan ${ }^{2}$, Nilgün Yenice ${ }^{3}$}

\section{Keywords}

1. Science teachers

2. Socioscientific issues

3. Teacher opinions

\section{Anahtar Kelimeler}

1. Fen bilimleri

öğretmenleri

2. Sosyobilimsel konular

3. Öğretmen görüşleri

Received/Başvuru Tarihi

07.08.2020

Accepted / Kabul Tarihi 20.01.2021

\section{Abstract}

The aim of this study is to explore the views of inservice science teachers on Socioscientific issues (SSI). The research was carried out by using the phenomenological research, which is one of the qualitative research methods. The participants of the study was formed by using the criterion sampling method, which is one of the purposeful sampling methods. The participants were 6 inservice science teachers working in the western part of Turkey. In present study, the interview form, developed by the researcherswere used as data collection tools. The data obtained from the research were transcribed. Written documents obtained were analyzed mature by content analysis in accordance with the qualitative research philosophy. As a result of the research, it has been observed that science teachers have different ideas about what SSI mean and have difficulties to get out of certain subjects in giving examples to SSI. When the place of SSI in science education was examined, it was found that the science teachers' opinions about the inclusion of SSI in science teaching is positive. It was seen that the participants had difficulty in giving examples to SSI that should not be discussed in the classroom. Suggestions were made in the light of the findings obtained from the present study.

Öz

Bu çalışmanın amacı, fen bilimleri öğretmenlerinin sosyobilimsel konular hakkındaki görüşlerini belirlemektir. Araştırma, nitel araştırma yöntemlerinden olgubilim deseni kullanılarak gerçekleştirilmiştir. Araştırmanın çalışma grubu, amaçsal örnekleme yöntemlerinden ölçüt örnekleme yöntemi kullanılarak oluşturulmuş olup, Türkiye'nin batısında İ Milli Eğitim Müdürlüğü bünyesinde görev yapan 6 Fen Bilimleri öğretmeninin katılımıyla gerçekleştirilmiştir. Araştırmada veri toplama aracı olarak araştırmacılar tarafından oluşturulan ve fen bilimleri alanında uzman iki öğretim üyesinin görüşleri alınarak son hali verilen görüşme formu uygulanmıştır. Araştırmadan elde edilen veriler transkript edilmiştir. Elde edilen yazılı dokümanlar araştırma problemine cevap olacak şekilde nitel araştırma felsefesine uygun olarak içerik analizi ile incelenmiştir. Araştırma sonucunda, fen bilgisi öğretmenlerinin sosyobilimsel konuların ne anlama geldiği konusunda farklı fikirlere sahip olduğu ve sosyobilimsel konulara örnek vermede belli konular dışına çıkmakta zorlandıkları görülmüştür. Öğretmenlerin gözünden sosyobilimsel konuların fen eğitimindeki yeri incelendiğinde ise fen bilgisi öğretmenlerinin sosyobilimsel konuların fen öğretimine dâhil edilmesi konusundaki fikirleri olumlu yönde olduğu tespit edilirken katılımcıların sınıf içerisinde tartışılmaması gereken sosyobilimsel konulara örnek vermekte zorlandıkları görülmüştür. Araştırmadan elde edilen bulgular ışığında önerilerde bulunulmuştur.

\footnotetext{
${ }^{1}$ Corresponding Author, Aydın Adnan Menderes University, Science Institute, Aydın, TÜRKIYE, tnmetin5@gmail.com , https://orcid.org/0000-0002-3753-8790 ${ }^{2}$ Aydın Adnan Menderes University, Faculty of Education, Department of Mathematic and Science Education, Aydın, TÜRKIYE, dilekkarisan@gmail.com, https://orcid.org/ 0000-0002-1791-9633

${ }^{3}$ Aydın Adnan Menderes University, Faculty of Education, Department of Mathematic and Science Education, Aydın, TÜRKIYE, nyenice@gmail.com, https://orcid.org/ 0000-0002-7935-3110
} 


\section{INTRODUCTION}

\subsection{Socioscientıfic Issues}

Through the rapid advances in technology and changes in science affect the society and social experiences faster. This change has also led to the emergence of dilemmas about many issues in terms of society. The issues that are considered as controversial issues we encounter as a result of the developments in science and technology and which are considered from different angles by different individuals in the society and of which positive and negative effects are evaluated in multiple ways are generally called socioscientific issues (Sadler, 2004; Topçu, 2015). In other words, socioscientific issues are those which cannot be easily described and ill-structured issues that do not have a single answer enabling the society to have different perspectives on the moral and ethical dimensions as well as the scientific dimension related to the subject. In order for a topic to be regarded as a socioscientific issue, it is not only necessary to include scientific and moral dimensions, but also to include the effects of developments in science and technology on social life. Socioscientific issues involve many dimensions such as science, social and ethical. These issues also play an important role in individuals' development and effective completion of their decision-making process. Such issues help individuals to develop effective discussion skills and to better understand the nature of science concepts such as critical thinking, problem solving, and conscious decision making (Erduran and Aleixandre, 2007).

In the study on socioscientific issues by Zeidler, Sadler, Simmons and Howes, (2005) it is emphasized that these issues may contribute to individuals' ability to think about scientific issues taking into consideration the ethical points. These are among the most popular and interesting issues of the 21st century in that they are mostly current issues, which, by their nature, involve scientific developments closely related to society and are covered in daily life and in education (Atalay and Çaycl, 2017). There are several studies on the socioscientific issues. For instance, Sadler and Zeidler (2004) considered individuals' ability to discuss and analyse socio scietific issues as one of the complementary elements of science literacy. The authors argued that socioscientific issues should be included in science education programs at the levels of secondary and university education. Türkmen, Pekmez and Sağlam (2017) argue that pre-service teachers should learn more socioscientific issues in the courses dealing with the correlations of the science-technology-society context which should employ student-centered methods and techniques provided that they start to learn such issues from basic education. Cebesoy and Dönmez Şahin (2013) examined whether the attitudes of pre-service science teachers on socioscientific issues significantly vary in relation to different variables and concluded that there was no such significant difference. Sezer (2017) compared the self-efficacy and attitudes towards socioscientific issues and self-efficacy towards science among two groups of teachers, namely in-service teachers and those who were not appointed. In the study the data were collected through the "scale of self-efficacy in science teaching" and the "scale of socioscientific attitudes". It is found that both groups of teachers have similar self-efficacy in regard to socioscientific issues and attitudes towards such issues. Türköz and Öztürk (2020) examined the pre-service science teachers' decisions and their justifications for these decsions concerning some socioscientific issues. They conclude that most of the preservice teachers, although they differ in relation to the subjects, take different dimensions into consideration when making their decisions and try to make decisions by considering the subject in a multi-dimensional holistic manner. Varal and Belge Can (2020) examined the qualifications of pre-service science teachers about the pedagogical content knowledge in the context of socioscientific issues. They conclude that the participants do not have adequate qualifications about the pedagogical content knowledge in terms of "students' comprehension of science" and "teaching strategies". Akbulut and Demir (2020) carried a study on a sample of science teachers to analyse their views on the methods and techniques used to teach socioscientific issues and on the effective teaching of these issues. The authors found that the most frequently used method is class discussions in the teaching of socioscientific issues and that the number of socioscientific issues covered in textbooks is not at the desired level. They suggested that such issues should be included more frequently in textbooks. El Arbid and Tairad (2020) examined the views of th science teachers in regard to the inclusion of the socioscientific issues in educational programs. They conclude that the participants have positive views concerning the inclusion of the socioscientific issues in educational programs. They also examined the positive and negative factors affecting the inclusion of the socioscientific issues in educational programs. In this regard they found that for the participants both teaching strategies and having necessary knowledge about these issues are two factors that faciliate the inclusion of the socioscientific issues in educational programs. For the participants the factors that make the inclusion of the socioscientific issues in educational programs difficult, including the cultural differences among students and their varying maturity levels. Nida, Rahayu and Eilks (2020) dealt with the Indonesian science teachers' experience and perceptions about science education involving the socioscientific issues. Nearly half of the participants are found to be familiar with the science education involving the socioscientific issues. The participants reported that major barriers in delivering science with socioscientific issues include limited student skills, the lack of knowledge and expertise among teachers and the centralized educational programs. They suggest that in order to reduce such problems sources on science teaching based on socioscientific issues should be designed and continous inservice training activities should be organized. Bayram- Jacobs et al. (2018) developed and implemented teaching materials on socioscientific issues to improve science teachers' pedagogical knowledge. In the study, convincing findings were obtained indicating that science teachers can improve their pedagogical content knowledge for socioscientific issues using a single module.

Majority of the studies on socioscientific issues carried out in Turkey focus on the views of the preservice teachers (Akbulut and Demir, 2020; Atalay and Çaycı, 2017; Kıvanç and Görgülü Arı, 2019; Sevim and Ayvacı, 2020; Türkmen, Pekmez ve

| Kastamonu Education Journal, 2022, Vol. 30, No. 1| 
Sağlam, 2017) and rare of them focused on elementary students' views on SSI (Yıldırım and Bakırcı, 2020) whereas international studies on socioscientific issues collect data from the inservice science teachers (Bosser ve Lindahl 2020; Friedrichsen, Ke, Sadler and Zangori, 2020; Gürbüzkol and Bakırcı, 2020; Tekgöz and Ercan Yalman, 2020). Although there are some studies in the latter group which analysed the views of the pre-service teachers' on socioscientific issues, the studies carried out in Turkey rarely deal with how socioscientific studies can be integrated into the courses. The socioscientific issues were first introduced among the science, technology, society and environment skills under the science education program in 2013. This group of skills aims at "making students capable of using their knowledge, skills and understandings acquired in science courses in the fields of economy, social relations and personal relations, to make informed evaluations about the actual scientific activities and to internalize the ecological, economical, social and cultural dimensions of the sustainable development". The science teachers are expected to integrate social scientific issues into secondary education courses and to provide efficient teaching of these issues. The aim of the study is to examine whether the opinions of the science teachers about teaching socioscientific issues differ based on their professional experience. In parallel to this aim the study attempts to answer the following research question:

What are the views of the inservice science teachers with varying professional experience about socioscientific issues?

\section{METHOD}

Since the aim of this study is to determine the views of the inservice science teachers about the teaching of the socioscientific issues, the phenomenology design, one of the qualitative research methods, was used in the study. In the phenomenological design the data are collected from the participants' views. In other words, phenomenology deals with the analysis of individuals' experience or their subjective evaluations about an event (Lester, 1999 cited in Özen and Karamustafaoğlu, 2019). In such studies the data analysis focuses on the individual experiences and the meanings attached to the phenomenon. The data collected are analysed using descriptive approach and direct quotations are frequently included. In additionthe findings obtained within the framework of emerging themes and patterns are explained and interpreted in such designs (Yıldırım and Şimşek, 2013). The focus in the study is the views of the science teachers concerning the teaching of socioscientific issues. The phenomenon analysed in the study is the views of the science teachers about the teaching of socioscientific issues.

\subsection{Participants}

In the phenomenological studies the participants should be selected with caution in that they should have direct experience on the topic at hand. The participants of the study are six science teachers working at public schools in Aydın. They were chosen using the criterion sampling method which is one of the purposive sampling. In criterion sampling the participants to be selected should bear some qualities. The participants are chosen based on these criteria (Büyüköztürk, Kılıç-Çakmak, Akgün, Karadeniz and Demirel, 2011). The criteria used were gender and having varying levels of professional experience. Therefore, three female and three male participants were selected. Concerning the professional experience the participants were divided into three categories: less experiences, medium-level experienced and very experienced. Less experienced teachers are those with a teaching experience of 1-10 years. Those with the medium-level experience have been teaching for the period of 10-20 years. Those classified as very experienced have a teaching experience of 20 years or more. Only one male participants was working at a village school and the others at urban schools. One of the female participants is a graduate of chemistry department. Demographical characteristics of the participants can be seen in Table 1.

Table 1. Demographical characteristics of the participants

\begin{tabular}{lccc}
\hline Codes for the teachers & Gender & Professional experience & Working place \\
\hline T1 & Male & 1 year (less experienced) & Village school \\
T2 & Female & 6 years (less experienced) & Central school \\
T3 & Male & 11 years (medium-level experienced) & Central school \\
T4 & Female & 15 years (medium-level experienced) & Central school \\
T5 & Male & 25 years (very experienced) & Central school \\
T6 & Female & 23 years (very experienced) & Central school \\
\hline
\end{tabular}

\subsection{Data Collection Tool}

Data were collected through an interview form which was developed by the authors and reviewed by two specialists in science teaching. Based on the feedback from the reviewers the form was finalized. Before the development of the interview form the studies on the teaching of the socioscientific issues were analysed and the missing points were identified in relation to the teacher views. The probing items were developed by a faculty member with speciality on science teaching who has studies on the teaching of the socioscientific issues and is an advisor of two master's thesis on the subject and a science teacher who 
took a course on the teaching of the socioscientific issues and is a graduate student. The items were reviewed by two other faculty members who have studies on the teaching of the socioscientific issues. Following the review by these specialists the form was also examined by another faculty member with speciality on Turkish language in terms of grammatical features and meaning. Then the interview form was reviewed. The interview form was administered to a science teacher who also had the qualities that were used to choose the participants. Following this the form was also used with three other science teachers in an interview. The final version of the interview form is composed of eight items (See Table 2).

Table 2. Themes used in the analysis and the related items

\begin{tabular}{|c|c|}
\hline Theme & Items \\
\hline \multirow{2}{*}{ Definition of the socioscientific issues } & Could you please define the socioscientific issues? \\
\hline & Could you please give examples to socioscientific issues? \\
\hline \multirow{4}{*}{$\begin{array}{l}\text { The place of the socioscientific issues in } \\
\text { science education }\end{array}$} & Should socioscientific issues be part of science education? Why? \\
\hline & Do you allocate time to teach socioscientific issues in the class? \\
\hline & If you think that the teaching of the socioscientific issues is important, what are the best \\
\hline & ways to integrate them into the science education? \\
\hline \multirow{3}{*}{$\begin{array}{l}\text { The place of the socioscientific issues in the } \\
\text { class }\end{array}$} & What are the socioscientific issues to be taught in the class? \\
\hline & Which points do you emphasize in teaching the socioscientific issues? \\
\hline & $\begin{array}{c}\text { Which methods and techniques do you use in making students aware of the socioscientific } \\
\text { issues? }\end{array}$ \\
\hline
\end{tabular}

Interviews are one of the most frequently employed data collection tools in qualitative studies. Although it seems to be much easier way of collecting data, both the data collection and data analysis should be carried out carefully. First the interview form should be designed well. Interview forms can be defined as forms that are developed to collect the views of individuals about the same topic. The items in the interview forms should cover all the points expressed in the research questions (Yıldırım ve Şimşek, 2013). The first author conducted the interviews in a silent office and the interviews were recorded. Each interview lasted nearly for 15-20 minutes.

\subsection{Data Analysis}

The interview data were first transcribed. Then these data were examined using the content analysis. The major goal in content analysis is to reveal the concepts and correlations about the topic at hand. In the data analysis similar concepts are coded and grouped under the themes (Yıldırım and Şimsek, 2013). Content analysis produces much deeper examination of the data in contrast to descriptive statistics. The coding were done by each author seperately. Then these codes were analysed and those which were mutually agreed were identified. Those for which the authors had different codings were further reviewed. Interrater reliability was found using the formula developed by Miles and Huberman (1994). The interrater reliability coefficient was found to be $75 \%$ in the first analysis. Following the review of the codings which were evaluated by the authors differently the analysis was repeated giving the reliability coefficient as $90 \%$. When the interrater reliability formula by Miles and Huberman (1994) is used, the coefficients higher than 70\% indicate the desired reliability. Therefore, the interrater reliability coefficient found in the study suggests that the study is reliable. In addition, direct quotations are included to improve the reliability of the study. Due to the ethical concerns, teachers names are not given instead the codes such as T1, T2, etc. were given to each teacher.

The awareness of the science teachers concerning the socioscientific issues is divided into three groups: high, medium and limited awareness groups. Of them the first group includes those who defined the socioscientific issues as the ones which cover both scientific and social dimensions and which are open-ended, mostly controversial and have no single answer. The second group refers to the participants who related socioscientific issues with society, but whose definitions lacked other significant characteristics of the socioscientific issues. The others were categorized in the third group, namely limited awareness group (Table 3).

\section{FINDINGS}

This section presents the discussion of the findings. It is organized around the interview items concerning the definition of the socioscientific issues, the place of the socioscientific issues in science education and their perceptions about these issues in regard to their place in classroom.

\subsection{Definitions of The Socioscientific Issues}

In order to reveal the perceptions of the participants they were asked to define the socioscientific issues in the interviews. 
Table 3. Inservice science teachers' socioscientific issues definitions

\begin{tabular}{|c|c|c|}
\hline Awareness level & Codes & Teacher codes \\
\hline \multirow{4}{*}{ Limited awareness } & Issues not covered in the educational program & T4 \\
\hline & More appropriate for the society & T6 \\
\hline & İssues that damage the structure of society & T5 \\
\hline & Disclosure of controversial scientific issues & T1 \\
\hline \multirow{4}{*}{ Medium-level awareness } & Issues that are intertwined with society & T5 \\
\hline & Issues open to incorrect or correct ideas & $\mathrm{T} 1$ \\
\hline & Environmental problems & $\mathrm{T} 2$ \\
\hline & Issues that are related to both social studies and science & $\mathrm{T} 2$ \\
\hline \multirow{4}{*}{ High-level awarenessa } & Controversial issues (Useful or not) & T3 \\
\hline & Issues that make it possible to gain different perspectives & T3 \\
\hline & Issues with no clear results & T4 \\
\hline & Issues which have scientific origins and are directly related to people & T5 \\
\hline
\end{tabular}

Only one of the participants provided a comprehensive definition of the socioscientific issues and was categorized as having high level of awareness about these issues. This science teacher had a medium-level of teaching experience. His views are given as follows:

...It should be socioscientific; some people argue that such issues are useful, but there are others who regard them as not useful... ( $\left.\mathrm{T}_{3}\right)$

It is found that three participants cannot use the concepts efficiently while defining the socioscientific issues. They are all classified as having medium-level awareness about these issues and have medium-level teaching experience. Direct quotations from their reports are given as follows:

... Issues that are initiated as scientific issues but become factors distorting the social structure of the society... ( $\left.\mathrm{T}_{5}\right)$

... having correct or incorrect views about a topic...( $\left.\mathrm{T}_{1}\right)$

...social scientific issues should cover both social sciences and science. For instance, environmental problems... ( $\left.\mathrm{T}_{2}\right)$

There are two participants who did not provide any definition of the socioscientific issues. These were very experienced science teachers, and they were not sure about their answers to the item. Their reports are given as follows:

... these issues may be those which are covered in the education progra, for instance, it may be evolution-related issues or should I think about the points related to the content of our courses?... ( $\left.\mathrm{T}_{4}\right)$

Table 4. Examples of SSI given by the inservice science teachers

\begin{tabular}{|c|c|c|}
\hline Theme & Examples & Teacher codes \\
\hline \multirow{6}{*}{ Science } & Cloning & T5-T6 \\
\hline & One Type Human & T4-T6 \\
\hline & Stem cells & T4 \\
\hline & DNA Replication & T4 \\
\hline & Gene Transfer & T6 \\
\hline & Gene Therapy & T6 \\
\hline \multirow{2}{*}{ Technology } & Technology addiction & $\mathrm{T} 2-\mathrm{T} 5$ \\
\hline & Social media addiction & $\mathrm{T} 2$ \\
\hline \multirow{3}{*}{ Energy sources } & Geothermal Energy & T3-T1-T6 \\
\hline & Hydroelectric Energy & $\mathrm{T} 1$ \\
\hline & Wind turbines & $\mathrm{T} 1$ \\
\hline \multirow{3}{*}{ Nutritions } & Genetically modified organisms & T5-T3-T6 \\
\hline & Pesticide & T3-T6 \\
\hline & Reclamation & T6 \\
\hline \multirow{3}{*}{ Environmental problems } & Global warming & $\mathrm{T} 2$ \\
\hline & Greenhouse effect & $\mathrm{T} 2$ \\
\hline & Environmental pollution & $\mathrm{T} 2$ \\
\hline \multirow{2}{*}{ Other } & Theories & $\mathrm{T} 4$ \\
\hline & Issues related to evolution & $\mathrm{T} 4$ \\
\hline
\end{tabular}

The second interview item asked the participants to give examples of the socioscientific issues. Half of the participants gave the examples of these issues such as geothermal energy or genetically modified organisms. They also provided other examples, 
including technology addiction, pesticides, cloning and single-type human beings (Table 4). These examples indicate that the participants perceive the socioscientific issues based on their observations about social events. There are also much more technical examples reported by the participants such as stem cell, DNA replication and gene transfer.

... I am not sure but I think the examples include genetically modified organisms, cloning and smart phones... (T5)

...Can environmental problems be given as examples? Global warming, greenhouse effect, environmental pollution. I think these are the examples of the socioscientific issues... $\left(\mathrm{T}_{2}\right)$

... cloning or genetically modified organisms are the examples. Should I give other examples?... ( $\left.T_{6}\right)$

\subsection{The Place of The Socioscientific İssues in Science Education}

In order to determine to what extent the participants in the study were aware of the importance of socioscientific issues in science education and to reveal their perceptions about the place of these subjects in science education, the items in the interview form were asked.

Table 5. Views of the inservice science teachers about the place of the socioscientific issues in science education

\begin{tabular}{|c|c|c|}
\hline Views & Reasons & Teacher codes \\
\hline \multirow{7}{*}{$\begin{array}{l}\text { These issues should be part of } \\
\text { the science education }\end{array}$} & science and socioscientific issues are interwoven & T1-T5-T3 \\
\hline & $\begin{array}{l}\text { socioscientific issues make it possible for students to } \\
\text { acquire distinct perspectives }\end{array}$ & T4-T3 \\
\hline & $\begin{array}{l}\text { socioscientific issues make the teaching environment much } \\
\text { more efficient }\end{array}$ & T6 \\
\hline & socioscientific issues attract student interest & T6-T1 \\
\hline & socioscientific issues improve students' reasoning skills & T3 \\
\hline & socioscientific issues should be taught in a seperate course & $\mathrm{T} 2$ \\
\hline & socioscientific issues make students to ready for daily life & T2-T5 \\
\hline $\begin{array}{l}\text { These issues should not be part } \\
\text { of the science education }\end{array}$ & - & 0 \\
\hline
\end{tabular}

Concerning the fact that the socioscientific issues are part of the science education all participants confirmed this view. More specifically, three of them reported that science and socioscientific issues are interwoven whereas two participants focused on the characteristics that may be taught to the students through such issues (Table 5). In addition, one participant reported that although the socioscientific issues are part of the science education, such issues can be taught in a seperate course. This teacher focused on environmental issues as can be seen in Table 3. Male participants mostly argued that that science and socioscientific issues are interwoven.

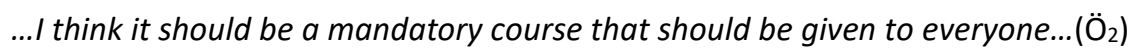

Another item asked to the participants during the interviews was follows: If you think that the teaching of socioscientific issues is significant, what is the best way to integrate them into science teaching?

The answers to this item are divided into four areas (Table 6). While increasing the number of seminars and conferences on socioscientific issues is the leading practice for students and parents, it is also reported by the participants that teachers should encourage students to make research on socioscientific issues, and the participants also argued that socioscientific issues should be included in the educational program more.

Table 6. Suggestions by the inservice science teachers to integrate the socioscientific issues into the science education

\begin{tabular}{|c|c|c|}
\hline Related groups & Practices & Teacher codes \\
\hline \multirow{4}{*}{ Students } & Making students much more involved in social events & T5 \\
\hline & Organizing visits & $\mathrm{T} 1-\mathrm{T} 2$ \\
\hline & Seminars & T1-T2 \\
\hline & Conferences & $\mathrm{T} 1-\mathrm{T} 2$ \\
\hline \multirow{3}{*}{ Teachers } & Directing students to make research & T4-T6 \\
\hline & $\begin{array}{l}\text { Identifying the outcomes and then, teaching them around the } \\
\text { socioscientific issues }\end{array}$ & T3 \\
\hline & $\begin{array}{l}\text { socioscientific issues should be taught not only in science courses but } \\
\text { also in other courses }\end{array}$ & $\mathrm{T} 2$ \\
\hline \multirow{2}{*}{ Parents } & Seminars & T1-T2 \\
\hline & Conferences & $\mathrm{T} 1-\mathrm{T} 2$ \\
\hline Educational programs & Covering the socioscientific issues more in the educational programs & T3 \\
\hline
\end{tabular}


Teachers with moderate professional experience have the idea that the work to be done should be directed to teachers and the educational program. Very experienced teachers think that the studies should focus on students and teachers. Some direct quotations on this regard are given as follows:

...You know what we can do some activities such as seminars, conferences, and these can be given to the parents and the students to make them informed about socioscientific issues.... $\left(\mathrm{T}_{2}\right)$

...related acquisitions can be determined, first we can start by determining the outcomes. Then, by integrating these acquisitions in appropriate courses, they can be taught in the lessons... ( $\left.\mathrm{T}_{3}\right)$

In order to reveal the views of the participants concerning the place of socioscientific issues in the teaching of science lessons, the item "Do you allocate time for teaching the socioscientific issues in your class?" was asked to the participants.

Tablo 7. Reasons for covering the socioscientific issues in science courses

\begin{tabular}{lcc}
\hline View & Reason & Teacher codes \\
\hline Exactly refers SSI in Science lessonsissues & Students like it & T1-T6 \\
\hline \multirow{2}{*}{ Refers SSI in science lessons } & It requires the ability to make decisions based on scientific data & T3-T5 \\
& Issues from daily life & T3 \\
\hline \multirow{2}{*}{ Limited refers SSI in science lessons } & within the educational program & T2-T4 \\
& Time constraints & T2 \\
\hline
\end{tabular}

While all of the participants stated that they allocate time for socioscientific issues in their lessons, it is determined that the time they allocated for the teaching of such issues differs according to some variables. While two of the participants emphasized that the students liked these issues, another two participants stated that they devoted time to such issues in their lessons since these issues improved the reasoning skills of their students. Two teachers, who said that they spend less time on socioscientific issues compared to other teachers, stated that they had difficulty in allocating time to these issues due to the intensity of science lessons. It is noteworthy that the teachers who have difficulty in allocating time to socioscientific issues in their lessons are female teachers who are at the early and middle stage of their careers. The participants devote time to these subjects in lessons in that these subjects contribute to the acquisition of some skills by students (Table 7). Some related direct quotations are given as follows:

... For example, our issues are already bio-technology and genetic engineering, and children like these issues very much... ( $\left.\mathrm{T}_{1}\right)$

... Children can at least learn through the real scientific data, not through the hearsay information, and they can form a mindset accordingly. Therefore, they may evaluate the positive and negative dimensions of these issues based on their mindset.... $\left(T_{3}\right)$

... Although I allocate time to teach these issues, it may not be sufficient due to the fact that the content of our course is very demanding and there is time restrictions...( $\left.\mathrm{T}_{2}\right)$

\subsection{The Place of Socioscientific Issues in Class}

Answers of the participants to a few questions in the interview form were evaluated together to reveal how the participants perceived the place of socioscientific issues in the classroom and how they implemented them.

Tablo 8. Socioscientific issues that should and should not be discussed in science classes

\begin{tabular}{|c|c|c|}
\hline Views & İssues & teacher codes \\
\hline \multirow{8}{*}{ Should be discussed } & genetically modified organisms & T3-T6 \\
\hline & pestices & T3 \\
\hline & DNA & T1-T4 \\
\hline & Organ donation & T4-T2-T6 \\
\hline & Renewable energy (GPP, HEPP, RES) & $\mathrm{T} 1$ \\
\hline & Technology addiction & T2-T4 \\
\hline & Social media addiction & $\mathrm{T} 2$ \\
\hline & Consanguineous marriage & $\mathrm{T} 1$ \\
\hline \multirow{2}{*}{ Should not be discussed } & Child abuse & $\mathrm{T} 2$ \\
\hline & political issues & T5 \\
\hline
\end{tabular}

The findings indicate that the issues taught in the class by four participants and their examples for the socioscientific issues are consistent (See Tables 4 and 8). There are two participants who stated that such issues as child abuse and political issues should not be discussed in the class. Given that the socioscientific issues do not cover such points, it is possible to argue that these participants seem to have misconceptions about the socioscientific issues (Table 8). The latter group of participants includes a novice female teacher and an very experienced male teacher. The related direct quotations are given below:

...I think there are some scio scientific issues that should not be discussed in the classroom, such as child abuse...( $\left(\mathrm{T}_{1}\right)$ 
... There are some political implications of some issues, and I avoid discussing or mentioning them in the classroom... ( $\left.\mathrm{T}_{5}\right)$

Another item in the interview form is as follows: While teaching the socioscientific issues in the classroom which points do you take into consideration?

Table 9. Points to be considered in teaching of the socioscientific issues

\begin{tabular}{lcc}
\hline Views & Reason & Teacher codes \\
\hline \multirow{3}{*}{ Should not be discussed } & These issues improve the children's perspectives & T4-T5-T6 \\
& These issues make them ready for daily life & T2-T3-T1 \\
& These issues are consistent with social norms & T5 \\
Should not be discussed & Problematic & T6-T4 \\
& controversial issues in terms religious beliefs & T4 \\
& political issues & T5 \\
\hline
\end{tabular}

Half of the participants agreed that discussing the socioscientific issues in the classroom would improve students' horizons and prepare them for daily life, while the other half of the participants reported that discussing some issues in the classroom would be troublesome, especially when these issues are concerned with students' religious beliefs and political views (Table 9).

Those teachers who did not provide any example for the socioscientific issues argued that the discussion of some issues in the classroom should be done with caution (see Tables 8 and 9). As can be seen in Table 9 such sensitivity is mostly expressed by very experienced teachers in contrast to less and middle-level experienced teachers. Some related quotations are given as follows:

...As you said in such different comments, it is a subject that is questioned in terms of religion, but we are comfortable to discuss such issues... ( $\left.T_{6}\right)$

... There are some political implications of some issues, and I avoid discussing or mentioning them in the classroom...( $\left(T_{5}\right)$

... Accordingly, they can shape their lives or direct their thoughts... $\left(\mathrm{T}_{3}\right)$

The interview item which is about the methods and techniques to teach the socioscientific issues is as follows: Which methods and techniques do you use to teach the socioscientific issues ?'

Table 10. Methods and techniques

\begin{tabular}{|c|c|c|}
\hline Category & Methods and techniques & Teacher codes \\
\hline \multirow{4}{*}{ Methods } & Discussion & T3-T6 \\
\hline & Debates & T3-T6 \\
\hline & Verbal lectures & T1-T4 \\
\hline & Case studies & T3 \\
\hline \multirow{2}{*}{ Techniques } & Question-answer sessions & $\mathrm{T} 1$ \\
\hline & Brainstorming & T1-T5 \\
\hline \multirow{5}{*}{ Other } & smart boards & T5-T6 \\
\hline & Visuals & T1-T4-T6 \\
\hline & Cause-effect relations & T6 \\
\hline & Observations & $\mathrm{T} 2$ \\
\hline & Research & T1-T4 \\
\hline
\end{tabular}

The answers of the four participants did not include any method and technique. Instead, they stated that they employed smart borads, visuals and inquiry strategies in teaching the socioscientific issues. Half of the participants reported that they used such methods and techniques as lectures, class discussions, debates and brainstorming, etc. (Table 10).

Those participants with less or middle-level teaching experience seem to be much more aware of the methods and techniques whereas those who are very experienced in teaching are found to less mention methods and techniques (Table 10).

\section{DISCUSSION}

In this study, the views of a group of inservice science teachers teaching at public schools in a province in Turkey's western region about the teaching of the socioscientific issues were analysed in relation to some variables, including gender, professional teaching experience, the location of the school they are working at and their educational background. The views of the teachers participating in the study on the socioscientific issues, which have an important role in raising the sensitive citizens of future, were examined. In this study, the questions asked to the science teachers were categorized under three main themes.

The first theme is the definition of the socioscientific issues. It is observed that the science teachers have different ideas about what the socioscientific issues mean and that they have difficulty in going beyond certain subjects while giving examples concerning the socioscientific issues. It is also found that most of the science teachers are aware that the socioscientific issues include scientific subjects, but they have difficulty in associating these issues with the society and social issues. Teachers who 
associate the socioscientific issues with society reported that the socioscientific issues are of a nature that disrupts the structure of society. Many of the teachers participated in the study appear to think this way. The reason for that may be that like most of the people the participants consider the national and international natural events, wars and theft, harassment and moral crimes etc. under this heading (Türkmen, Pekmez and Sağlam, 2017). It is found that highly experienced teachers have more difficulty in defining the socioscientific issues than teachers with low and intermediate professional experience. The reason for this can be that the socioscientific issues were first included in the science education program under the title of science-technology-societyenvironment in the 2013 program developed by the Ministry of Education. When the examples given as socioscientific issues were examined, it is seen that the examples given were concentrated within the framework of social issues that can be observed in the living environment. In other words, the participants mostly reported examples from their immediate environment. It is seen that individuals take a more active role in solving socioscientific problems in their immediate surroundings and are less concerned about socioscientific issues in their distant environment. Şama (2003) reports similar findings in the study which was carried out on sample of preservice teachers and which analysed their attitudes towards environmental probblems. The middlelevel and highly experienced teachers who participated in the study gave more examples of the science-themed socioscientific issues compared to teachers with less experience. Teachers with less teaching experience gave environmental issues as an example of these issues. This situation can be attributed to the multidimensional nature of the socioscientific issues. Particularly the rapid changes and developments in science and technology affect social life directly and indirectly over time (Atalay and Çaycl, 2017). It can be related to the fact that teachers with low and medium level professional experience witness scientific changes compared to very experienced teachers who witness the effects of these changes on the environment and society. This may explain why less experienced teachers more frequently provided examples of the socioscientific issues such as environmental problems compared to intermediate and very experienced teachers.

The second main theme is the place of the socioscientific issues in science education. Science teachers' opinions about the inclusion of the socioscientific issues in science teaching are positive. Especially, it is seen that they mostly reported that the science and socioscientific issues are intertwined. It is also noteworthy that the socioscientific issues are used as a tool to attract teachers' attention in science education. The use of the socioscientific issues for this purpose is commonly stated in the related studies. In the study conducted by Karman, Yılmaz-Tüzün and Zeidler (2018) on the examination of the reflective reasoning skills of the preservice teachers in the science laboratory applications about the socioscientific issues, it was observed that the socioscientific issues directly connected to the lives of the participants, initiated their curiosity and encouraged their active participation and personal participation. Another reason why teachers want the socioscientific issues to be a part of science teaching is the idea that the skills to be acquired by students through such issues will be beneficial for them to become conscious individuals. As a matter of fact, it is supported to include discussions on socioscientific issues in the classroom in many studies conducted so far (Acar, Türkmen, \& Roychoudhury, 2010; Zeidler et al., 2005). The activities to be done for the inclusion of the socioscientific issues in science teaching in the classroom were examined under four headings. It is observed that less experienced teachers who are in the first years of their careers have the view that activities should be done for students and parents, and those with moderate experience argued that such activities would facilitate the inclusion of the socioscientific issues in science teaching. Very experienced teachers think that the activities should focus on students and teachers. Nida, Rahayu, and Eilks (2020) in their study investigating the experiences and perceptions of Indonesian science teachers towards science teaching based on the socioscientific issues found that the main obstacles to the socioscientific issues are the limitations in students' skills, teachers' lack of knowledge and expertise, and the standard educational program. Although it does not explain the reason for the disagreement of moderately experienced and highly experienced teachers, it explains why the socioscientific issues are gathered in this framework at the point of including science teaching. In the study of Nida et al. (2020) it is also determined that designing science learning materials focused on the socioscientific issues and continuous professional development seminars on the use of these designs are the best option to overcome these obstacles. However, the significance of the science education focused on the socioscientific issues is increasing today. In addition, it has become even more important for teachers to be experienced individuals who are interested in these issues that they frequently encounter in the media or their environment and can give the necessary feedback to their students (Sadler, 2011). As a result of the interviews with the participants, the fact that there are teachers who have difficulty in allocating time to the socioscientific issues due to the intensity of the educational program suggests that the changes to be made in the educational program will be more effective in covering the socioscientific issues in science teaching. Those with moderate experience argued that activities should focus on teachers and students to facilitate the inclusion of the socioscientific issues in science teaching. This situation may indicate that the teachers participated in the study can not go beyond the objectives covered in the educational program and therefore, it supports the idea that the socioscientific issues should be emphasized much more frequently. It is also observed that all teachers who participated in the study devoted time to the socioscientific issues in the class, but those who had difficulty in using their time for such issues compared to the other teachers were less experienced and moderately experienced female teachers.

The third themes about the place of the socioscientific issues in the class. It is noteworthy that the participants gave similar answers in regard to the socioscientific issues that need to be addressed in the classroom. However, when asked about the socioscientific issues that should not be discussed in the classroom, it is observed that most of the teachers had difficulty in giving examples of such issues. There are other participants who provided irrelevant examples such as child abuse and political issues suggesting that they have some misconceptions concerning the socioscientific issues. It is important to note that the 
participants did not consider the socioscientific issues as controversial issues in which the positive and negative effects of developments in science and technology are evaluated, and instead, they consider those issues that do not have a scientific basis as socioscientific issues. Teachers who are expected to improve students' reasoning skills by carrying science-based controversial issues to the classroom ignore the science-based feature of the socioscientific issues. They also consider only socially based issues as the socioscientific issues and argue that it is not appropriate to discuss such issues in the classroom. All of these misunderstandings create an obstacle to the transfer of the socioscientific issues to the educational practices. Therefore, it becomes difficult to acuire the skills such as critical thinking, scientific discussion, and effective communication, which are expected to be added to students through the socioscientific issues. It is also observed that highly experienced teachers are more sensitive concerning the socioscientific issues compared to less and moderately experienced teachers. The reason for this may be that teachers who have more professional experience have been more exposed to such situations and are more sensitive to those issues that may cause problems in the classroom over time. Gündüz and Çelikkaleli (2009) examined the beliefs of school psychological counselors in their professional competencies based on the variables of service duration, and found that psychological counselors with more experience were more competent in using their skills than psychological counselors with less experience.

In addition, regarding the methods and techniques used for teaching the socioscientific issues it is found that the participants mostly used smart boards, visual sources and observations, etc. It is seen that they gave answers not directly related to the methods and techniques used in the teaching of the socioscientific issues. It is seen that these participants are mostly those teachers with high and medium level experience. It is also observed that some of the teachers benefited from the methods and techniques such as lectures, class discussions, debate, and brainstorming in teaching the socioscientific issues.

It is clearly seen that the science teachers who participated in the study have some opinions about the socioscientific issues, but they did not have enough information to express their opinions about the three major themes. It is also observed that less experienced teachers were more conscious in explaining the socioscientific issues, determining their place in science teaching and in the classroom. It is found that most of the teachers avoided the effects that the ethical and moral dimensions of the issues covered in the classroom, and they particularly avoided handling such issues in the classroom.

\section{CONCLUSION AND SUGGESTIONS}

The number of participants can be increased to obtain more generalizable results. The opinions of not only science teachers but also teachers who teach in other branches (e.g. social studies) that may be related to socio-scientific issues can be taken on these issues. In addition, by increasing the number of participants, the demographic characteristics of science teachers can be diversified, and teachers' opinions can be analysed based these variables. Those socio-scientific issues specified by the teachers who participated in the study can be used to increase students' individual decision-making and reasoning skills. In addition, the factors of teachers and parents stated in the findings can be taken into consideration, and the effects of these components on the teaching of socio-scientific issues can be examined more deeply.

In line with the suggestions of the science teachers who participated in the current study, teachers can be given seminars on the content of the revised science education program, its learning areas, practical examples concerning the various methods and techniques, practical in-service trainings and learning approaches that may be employed. Quantitative studies can be conducted by developing data collection tools to determine science teachers' perceptions about the socio-scientific issues and their opinions on teaching these subjects. In this way, a wider impact can be achieved by reaching more participants. A teaching model for this activity can be developed in Turkey, and its efficiency can be evaluated. Those socio-scientific issues related to the science education can be added to undergraduate programs in the form of elective or compulsory courses. Within the scope of this course, pre-service teachers can be given an opportunity to be informed about these issues, to be aware of the subjects and to gain experience about the methods and techniques to be used in teaching the subjects before starting the teaching profession. Practical examples related to socio-scientific issues can be added to the science education program.

\section{Declaration of Conflicting Interests}

The authors declared no potential conflicts of interest with respect to the research, authorship, and/or publication of this article.

\section{Funding}

The authors received no financial support for the research, author-ship, and/or publication of this article.

\section{Statements of publication ethics}

We hereby declare that the study has not unethical issues and that research and publication ethics have been observed carefully. 


\section{Researchers' contribution rate}

First Author conceived of the presented idea. Second Author contributed to the theoretical framework. Third Author verified the analytical methods. Second and Third Author encouraged first author to investigate the research with in-service teachers and supervised the findings of this work. All authors discussed the results and contributed to the final manuscript.

The study was conducted and reported with equal collaboration of the researchers.

\section{Ethics Committee Approval Information}

Name of the Institution: Aydın Adnan Menderes University

Date: 09/07/2020

Number: 84982664-604.01.02

Subject: Resolution 2020/10-III

Ethics Committee Approval for the research was received with an official letter dated 09/07/2020 and numbered E.36160 from Aydın Adnan Menderes University Scientific Educational Research Ethics Committee that decision numbered 2020/10-III.

\section{REFERENCES}

Acar, O., Türkmen, L. ve Roychoudhury, A. (2010). Student Difficulties in Socio-Scientific Argumentaation and Decision-Making Research Findings: Crossing The Borders of Two Research Lines. International Journal of Science Education, 32(9), 1191-1206.

Akbuluti H.I. ve Demir, O. (2020). Science Teachers' Views of Socio Scientific Issues. International Journal of Progressive Education, 16(1), 237256.

Atalay, N. ve Çaycı, B. (2017). Sınıf Öğretmeni Adaylarının Sosyobilimsel Konular Hakkındaki Görüş ve Tutumlarının Farklı Değişkenlere Göre Incelenmesi. Estüdam Eğitim Dergisi, 2(2), 35-45.

Bayram Jacobs, D., Henze, I., Evagorou, M., Shwartz, Y., Aschim, E. L., Alcaraz-Dominguez, S., Barajas, M., \& Dagan, E. (2019). Science teachers' pedagogical content knowledge development during enactment of socioscientific curriculum materials. Journal of Research in Science Teaching, 56(9), 1207-1233.

Bosser, U. ve Lindahl, M. (2021). Teachers' Coordination of Dialogic and Authoritative Discourses Promoting Specific Goals in Socioscientific Issue-Based Teaching. International Journal of Science and Mathematics Education, 19, 461-482.

Büyüköztürk, Ş., Kılıç-Çakmak, E., Akgün, Ö.E., Karadeniz, Ş. ve Demirel, F. (2011). Bilimsel Araştırma Yöntemleri. (8. Baskı). Ankara: Pegem Akademi

Cebesoy, B.Ü. ve Dönmez-Şahin, M. (2013). Fen Bilgisi Öğretmen Adaylarının Sosyobilimsel Konulara Yönelik Tutumlarının Çeşitli Değiş̧kenler Açısından İncelenmesi. M.Ü Atatürk Eğitim Fakültesi Eğitim Bilimleri Dergisi, 37(37), 100-117.

El Arbid, S. S., \& Tairab, H. H. (2020). Science Teachers' Views about Inclusion of SocioScientific Issues in UAE Science Curriculum and Teaching. International Journal of Instruction, 13(2), 733-748.

Erduran, S. ve Jiménez-Aleixandre, M. P. (2007). Argumentation in Science Education: Perspectives from Classroom-Based Research. Springer.

Friedrichsen, P.J., Ke, L., Sadler, T. D. ve Zangori, L. (2020). Enacting Co-Designed Socio-Scientific Issues-Based Curriculum Units: A Case of Secondary Science Teacher Learning, Journal of Science Teacher Education.

Gündüz, B. ve Çelikkaleli Ö. (2009). Okul Psikolojik Danışmanlarında Mesleki Yetkinlik İnancı. Mersin Üniversitesi Eğitim Fakültesi Dergisi, 5 (1), 119-133.

Gürbüzkol, R. ve Bakırcl, H. (2020). Fen bilimleri öğretmenlerinin sosyobilimsel konular hakkındaki tutum ve görüşlerinin belirlenmesi. YYü Eğitim Fakültesi Dergisi, 17(1), 870-893.

Karışan, D., Yılmaz-Tüzün, Ö. ve Zeidler, D.L. (2018). Pre-Service Teachers' Reflective Judgment Skills in The Context of Socio-Scientific Issues Based Inquiry Laboratory Course. Turkish Journal of Education, 7(2), 99-115.

Kıvanç, Z. ve Görgülü-Arı, A.(2019). Fen Bilgisi Öğretmen Adaylarının Biyoteknoloji ve Genetiği Değiştirilmiş Organizma (GDO) Konularında Tutumlarının Değerlendirilmesi. Adnan Menderes Üniversitesi Eğitim Fakültesi Eğitim Bilimleri Dergisi, 10 (1), 37-57.

Miles, M, B., ve Huberman, A. M. (1994). Qualitative data analysis: An expanded Sourcebook. (2nded). Thousand Oaks, CA: Sage.

Milli Eğitim Bakanlığı Talim ve Terbiye Kurulu Başkanlığı, (2013). ilköğretim Fen ve Teknoloji Dersi (6, 7, 8. Sınıflar) Öğretim Programı. MEB Ankara.

Nida, S., Rahayu, S., \& Eilks, I. (2020). A survey of Indonesian science teachers' experience and perceptions toward socio-scientific issues-based science education. Education Science, 10(2), 1-15.

Özen, H. ve Karamustafaoğlu, O. (2019). Eğitimde Araştırma Yöntemleri. (1. Baskı). Ankara: Pegem Akademi.

Sadler, T.D. (2004). Informal Reasoning Regarding Socio-Scientific issues: A Critical Review Of Research. Journal of Research in Science Teaching, 41, 513-536.

Sadler, T. D. ve Zeidler, D. L. (2004). The Morality of Socioscientific Issues Construal and Resolution of Genetic Engineering Dilemmas. Science Education, 88(1), 4-27.

Sadler, T. D. (2011). Situating Socio-Scientific Issues in Classrooms as A Means of Achieving Goals of Science Education. T. D. Sadler (Ed). SocioScientific Issues in The Classroom: Teaching, Learning And Research (pp. 1-10). New York: Springer. 
Sevim, S. \& Ayvacı, H. Ş. (2020). Öğretmen adaylarının sosyo-bilimsel konulardaki inançları: Nükleer enerji. Eskişehir Osmangazi Üniversitesi Türk Dünyası Uygulama ve Araştırma Merkezi (ESTÜDAM) Eğitim Dergisi, 5 (1), 25-39.

Sezer, K. (2017). Görev Yapan ve Atanmamış Fen Bilimleri Öğretmenlerinin Sosyobilimsel Konularla Ilgili Öz Yeterlilik ve Tutumlarının Belirlenmesi (Samsun Ili Örneği). Yüksek Lisans Tezi, Ondokuz Mayıs Üniversitesi, Samsun.

Şama, E. (2003). Öğretmen Adaylarının Çevre Sorunlarına Yönelik Tutumları. G.Ü. Gazi Eğitim Fakültesi Dergisi, 23(2), 99-110.

Tekgöz, T., \& Ercan-Yalman, F. (2020). Nükleer santraller hakkında fen bilgisi öğretmenlerinin görüşü: Akkuyu örneği. Muğla Sıtkı Koçman Üniversitesi Eğitim Fakültesi [MSKU Journal of Education], 7(2), 144-158.

Topçu, M. S. (2015). Sosyobilimsel Konular ve Öğretimi. Ankara: Pegem Akademi.

Türkmen, H., Pekmez, E., ve Sağlam, M. (2017). Fen Bilgisi Öğretmen Adaylarının Sosyobilimsel Konular Hakkındaki Düşünceleri. Ege Eğitim Dergisi, 18(2), 448-475.

Türköz, G. ve Öztürk, N. (2020). Fen bilgisi öğretmen adaylarının bazı sosyo-bilimsel konularla ilgili kararlarının çok boyutlu bakış açısı ile incelenmesi. Cumhuriyet International Journal of Education, 9(1), 175-197.

Varal, E. ve Belge Can, H. (2020). Fen Bilgisi Öğretmen Adaylarının Sosyobilimsel Konular Bağlamında Pedagojik Alan Bilgilerinin İncelenmesi. Mehmet Akif Ersoy Üniversitesi Eğitim Bilimleri Enstitüsü Dergisi, 8(10), 21-42.

Yıldııım, İ., \& Bakırcı, H. (2020). Ortak Bilgi Yapılandırma Modeline Dayalı Fen Öğretiminin Sekizinci Sınıf Öğrencilerinin Sosyobilimsel Konular Hakkındaki Görüşlerine Yansımasının İncelenmesi. Inönü Üniversitesi Eğitim Fakültesi Dergisi, 21(2), 1051-1070.

Yıldırım, A.ve Şimşek, H. (2013). Sosyal Bilimlerde Nitel Araştırma Yöntemleri. (9. Baskı). Ankara: Seçkin Yayınevi.

Yücel, M., Altunkasa, F., Güçray, S., Uslu, C. ve Say, N.P. (2006). Adana'da Çevre Duyarlıığı Düzeyinin ve Geliştirme Olanaklarının Araştırıması. Akdeniz Üniversitesi Ziraat Fakültesi Dergisi, 19(2), 217-228.

Zeidler, D. L., Sadler, T. D., Simmons, M. L. ve Howes, E. V. (2005). Beyond STS: A research-based framework for socioscientific issues education. Science Education, 89(3), 357-377. 